\title{
Studies on microparticles contained in medium-depth ice cores retrieved from east Dronning Maud Land, Antarctica
}

\author{
AKIRA HIGASHI * \\ International Christian University, Mitaka-shi, Tokyo 181, Japan \\ Yoshiyuki FujII \\ Nalional Institute of Polar Research, Itabashi, Tokyo 173, Japan
}

\begin{abstract}
SEM observations of microparticles in ice-core samples retrieved by the Japanese Antarctic Research Expedition in east Dronning Maud Land have been carricd out sincc 1987. Morphology and elemental composition by EDS of many microparticles taken from various depths of the $700 \mathrm{~m}$ Mizuho icc core were compared with each other and with those of stratospheric microparticles in NASA Cosmic Dust Catalogs and microparticles hitherto found in deep ice cores retrieved in Antarctica. Number concentrations of microparticles were measured on all samples throughout the $700 \mathrm{~m}$ Mizuho ice core. Remarkable fluctuations found in the depth profile of the concentration seem to coincide with cold climates indicated by $\delta^{18} \mathrm{O}$ of the same core. Compositional analysis of volcanic ash at a depth of $500.7 \mathrm{~m}$ in the Mizuho ice core, datcd at approximately 6000 years BP, indicates that the ash originated from the South Sandwich Islands.
\end{abstract}

\section{INTRODUCTION}

The Antarctic continent, which is far from acrosol dust sources and mostly covered by snow and ice, is considered to be an ideal site for studying the background of global dustfall and the long-range transport processes by acrosols. It is known that microparticle concentrations in deep ice cores increased during the last glacial period, and this increase is considered to have resulted from the paleoclimate conditions of the ice age characterized by an increase in arid regions and more vigorous atmosphcric circulation (Briat and others, 1982). Studies of the volcanic ash occasionally found in ice cores are important for understanding global volcanic activity in the past and also for comparison of the chronology of ice cores at different sites (Palais and others, 1987).

In the present study, microparticles collected at $10 \mathrm{~m}$ depth intervals throughout the $700 \mathrm{~m}$ Mizuho ice core were observed using a scanning clectron microscope (SEM). Simultaneously, elemental composition analysis was carried out for each observed particle by the method of energy-dispersive X-ray spectroscopy (EDS). Comparing morphological characteristics and quantitative compositions by EDS (spectra shown in the recording chart illustrated here) with each other and with other microparticles found in various publications, the true characteristics and origins of the particles were invest-

\footnotetext{
* Present address: Tomigaoka 552-11, Hiroshima-cho, Hokkaido 061-11, Japan.
}

igatcd. The literaturc includes NASA's Cosmic dust catalog. (CDC) (e.g. NASA, 1992), Volcanic ash by Heiken and Wohletz (1985) and many other papers which are listed in the References. The number concentration of particles in the ice every $10 \mathrm{~m}$ was evaluated by counting numbers in low-magnification SEM photographs of specimens. The depth profile of the concentration shows a good correlation between the long-range increase of microparticles and the cold climatc in the Holocene.

Ice cores used for the study were retrieved at Mizuho Station $\left(70^{\circ} 12^{\prime} \mathrm{S}, 44^{\circ} 22^{\prime} \mathrm{E}\right.$, altitude $\left.2230 \mathrm{~m}\right)$ and at Advance Camp ' 85 ( $74^{\circ} 12^{\prime} \mathrm{S}, 34^{\circ} 59^{\prime} \mathrm{E}$, altitude $3200 \mathrm{~m}$ ). Although the Mizuho $700 \mathrm{~m}$ core was retrieved in the two austral winters of 1983 and 1984 , carlier than the AC $200 \mathrm{~m}$ core retrieved in the austral summer of 1985 , complete examinations of the former were not carried out till later than those of the latter, the results of which were published in our earlier paper (Higashi and others, 1990). Several volcanic ash particles collected from a visible ash layer found at $500.7 \mathrm{~m}$ depth in the Mizuho core (Fujii and Watanabe, 1988) were semiquantitatively analysed by EDS. From the results of the analyses, we have concluded that the ash, dated at approximately 6000 year BP, originated in the South Sandwich Islands, as is discussed below.

\section{METHODS}

\section{Samples}

Details of the sampling of microparticles from ice cores 
have been given in our earlier paper (Higashi and others, 1990). Ice samples of approximately $5 \mathrm{~cm}$ length (corresponding approximately to a little less than 1 year) were taken from vertically half-cut ice corcs at approximately $10 \mathrm{~m}$ intervals (covcring approximately $\sim 100-120$ years according to the analysis by Nakawo and others (1989)).

Meltwater of the inner part of every individual sample was filtered through a Nucleo filter $(0.6 \mu \mathrm{m}$ porc sizc) using a vacuum suction funnel. The sampling and filtering procedures were carried out in a cold room and a class-1000 clean chemistry laboratory at the National Institute of Polar Rcscarch, Tokyo, Japan, where the ice cores had been stored.

\section{SEM observations and EDS analyses}

The filters on which microparticles were deposited were transported to the electron-microscope laboratory of the International Christian University (ICU), Tokyo. A square-shaped piece of approximatcly $50 \mathrm{~mm}^{2}$ was cut from each Nucleo filter so that it covered equal parts of the center and the periphery. Then, it was stuck to a specimen holder and coated with evaporated carbon in a vacuum. The SEM is a JSM-T220, JEOL attached to a QX-200J, Link for the EDS analysis. For the quantitative elemental analysis using EDS, a cobalt standard and $\mathrm{ZAF} 4$ program were used. Since the specimen holder was made of brass, artifact peaks of $\mathrm{Zn}$ and $\mathrm{Cu}$ appear in the EDS spectra.

The number concentration of microparticles was evaluated from counted numbers of particles on low $(\sim 100-200$ ) magnification SEM photographs covering whole arcas of the filter examined, by a conversion equation as follows:

$$
N=0.05 \mathrm{mS} / \mathrm{s \nu}
$$

where $m$ is the number of particles on a photograph of the examined area $s$, and $S$ is the area of Nucleo filter through which $\nu \mathrm{ml}$ of meltwatcr was filtcred. The unit adopted here for the concentration is the number of particles in $0.05 \mathrm{ml}$ of water, the same unit customarily used for the Coulter-counter measurement. For comparison with the number concentration thus obtained, measurements by a Coulter counter of particles larger than $0.63 \mu \mathrm{m}$ were carried out on the same sample.

\section{RESULTS OF OBSERVATIONS}

\section{Number concentration of microparticles}

A depth profile of the number concentration of microparticles larger than $1 \mu \mathrm{m}$ in diameter counted on SEM photographs at every $10 \mathrm{~m}$ depth interval is shown by solid circles in Figure 1. Results of the Coulter-counter measurements on the same sample shown by horizontal bars in Figure 1) generally coincide with results of direct counting on SEM photographs. As can be seen in the figurc, the average particle concentration is of the order of $200 / 0.05 \mathrm{ml}$ meltwater throughout the $700 \mathrm{~m}$ depth. However, there appear to be some higher values at
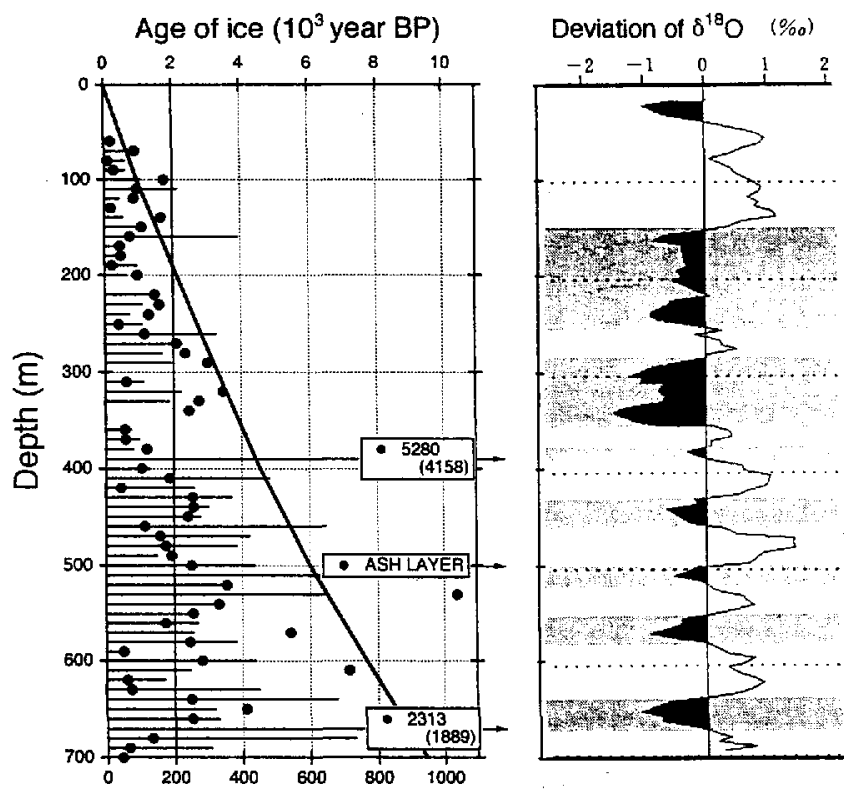

Number of particles in unit volume $(0.05 \mathrm{ml})$

\begin{abstract}
Fig. 1. Depth profile of the observed number concentration of microparticles (expressed by solid circles) in the Mizuho $700 \mathrm{~m}$ ice core, with a curve representing the depth-age relationship of the ice derived by Nakawo and athers (1989). Data of the Coulter-counter measurements are expressed by horizontal bars at each depth. The righthand side of the figure is the depth profile of the deviation $\Delta \delta^{18} O$ from a smoothed curce of the depth profile of $\delta^{18} \mathrm{O}$ (Fuiil and Watanabe, 1992).
\end{abstract}

certain depth ranges: $260-340,430 \cdot 450,500550,570$, 610 and $640-670 \mathrm{~m}$. Large single fluctuations occur at $390 \mathrm{~m}(5280 / 0.05 \mathrm{ml})$ and $670 \mathrm{~m}(2313 / 0.05 \mathrm{ml})$ depths, which correspond exactly to a large fluctuation in the microparticle concentration measured by the Coulter counter $(4158 / 0.05 \mathrm{ml}$ and $1889 / 0.05 \mathrm{ml}$, respectively). In addition, there is a visible volcanic ash layer at a depth of $500.7 \mathrm{~m}$, just between our 500 and $510 \mathrm{~m}$ sampling depths.

\section{Morphology and EDS analysis}

In our earlier paper (Higashi and others, 1990), the morphology of observed microparticles was tentatively classified in six primary categories: spherical particles $(S)$, micro-nodules $(N)$, aggregates of minute particles $(\Lambda p)$, aggregates of flat particles (Af), sharp-edged mineral fragments (M) and diatoms (D). By taking many SEM photographs accompanied by EDS charts, we have noticed that many particles categorized $N$, Ap and Af were almost the same in elemental composition, despitc the variation in their morphology. Although the morphology itself often tells little about the origin of the obscrved microparticles, we will give here some interesting examples.

A relatively large number of spherical particles (S) was found at various depths. There are two kinds of sphere: one with a characteristic surface feature as shown in Figure $2 a$, which is a reproduction of figure $3 \mathrm{~b}$ of our previous paper mentioned above. It is characterized by a single strong peak of $\mathrm{Fe}$ in the EDS chart. Judging from comparisons 

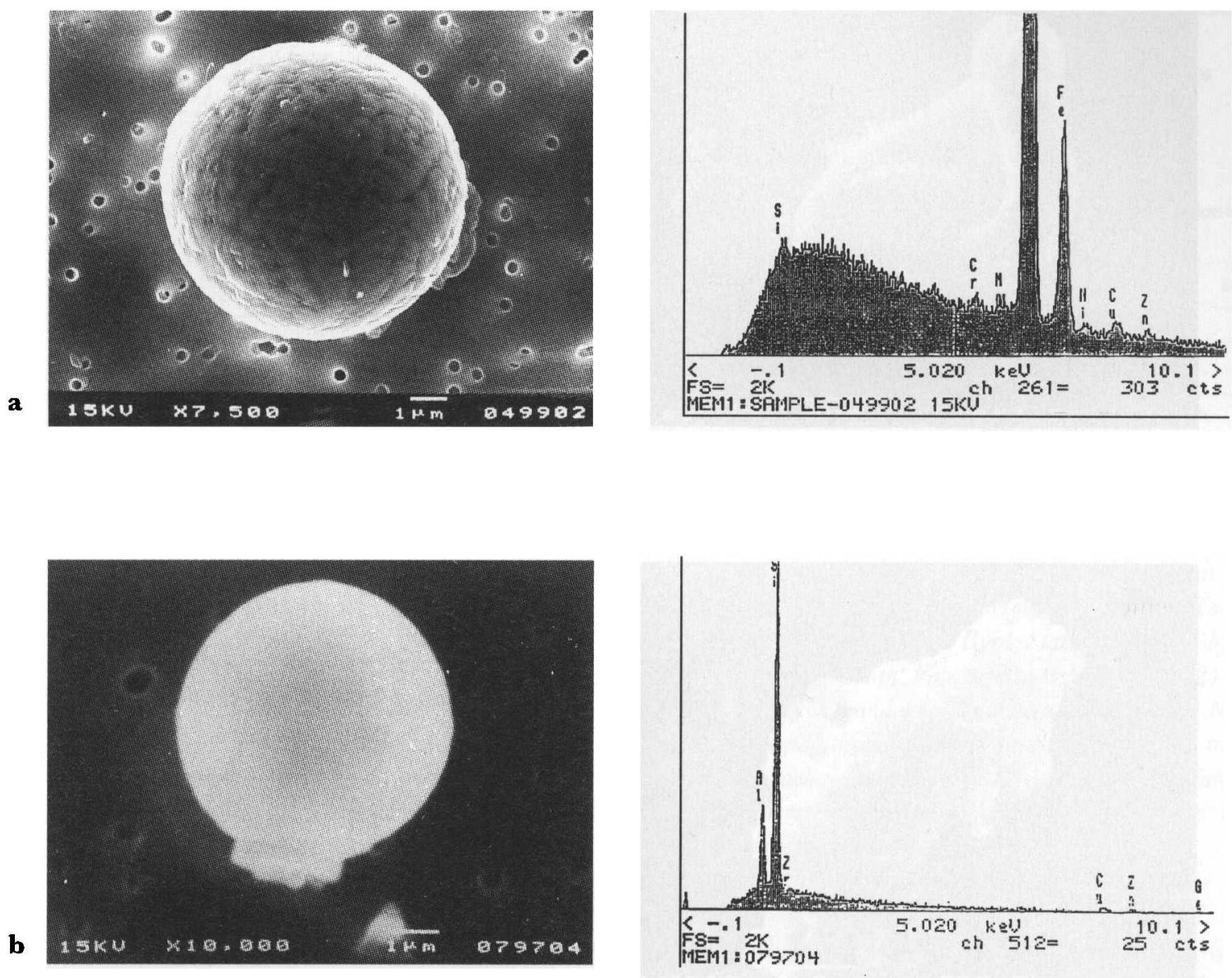

Fig. 2. SEM photographs, with EDS charts, of spherical particles. a. An iron micrometeorite found at $50 \mathrm{~m}$ depth in $A C$ core (approximately 560 year BP); b. A Si-rich spherical particle found at $520 \mathrm{~m}$ depth in the Mizuho ice core (appraximately 6400 year $B P$ ).

with many spherical microparticles catalogued in the Cosmic dust catalog, Volume 13 (NASA, 1992), it is concluded that such iron spheres are iron micro-meteorites.

Another kind of spherical particle has a smooth surface with a high pcak of $\mathrm{Si}$ in the EDS chart, as shown in Figure 2b. This particle was obtained from $520 \mathrm{~m}$ depth of the Mizuho ice core, and an identical one was obtained from $450 \mathrm{~m}$. The origin of these particles is not clear at present.

Common elemental compositions seen in the EDS chart of various microparticles categorized $\mathrm{N}, \mathrm{Ap}$ and $\mathrm{Af}$ are as shown in Figure $3 \mathrm{a}$ and $\mathrm{b}$. The particle in Figure $3 \mathrm{a}$ from $510 \mathrm{~m}$ depth in the Mizuho core has a peculiar convolute shape, while the particle in Figure $3 \mathrm{~b}$ from $570 \mathrm{~m}$ depth looks like an aggregate of minute particles. Both EDS spectra exhibit high peaks at $\mathrm{Al}$ and $\mathrm{Si}$ with side peaks at $\mathrm{S}$ and $\mathrm{Cl}$, but Figure 3 a lacks $\mathrm{Ca}$ which appears in Figure $3 \mathrm{~b}$. We often see a $\mathrm{K}$ peak instead of or as well as a Ca peak in the spectra. The most likcly mineral of this composition is feldspar. Differences in morphology must be due to differences in their origin.

Our SEM photographs show particles which are similar to tephra from Byrd Station, South Pole and Vostok ice cores described by Palais (1985) and Palais and others $(1987,1992)$. Two examples of particles which look like volcanic glass shards are shown in Figure $4 \mathrm{a}$ and b. The former is from $220 \mathrm{~m}$ depth and the latter from $410 \mathrm{~m}$ depth, both from the Mizuho ice core. Both EDS charts show $\mathrm{Na}$ and $\mathrm{K}$ peaks beside the main strong peaks of $\mathrm{Si}$ and $\mathrm{Al}$, as an expected characteristic of volcanic ash. Other examples of the volcanic ash will be given in the next sub-section.

Diatoms and sponge spicules were often found in the Mizuho ice core, and particles which look like spores and pollen were found in both the Mizuho ice core and in the surface snow. Details of these particles are not presented here because of limited space in this paper.

\section{Volcanic ash at $500.7 \mathrm{~m}$ depth in the Mizuho ice core}

$\Lambda$ visible volcanic ash layer was found at approximately $500.7 \mathrm{~m}$ depth in the Mizuho ice corc (Fujii and Watanabe, 1988). The $50 \mathrm{~cm}$ ice-core sample which contained the ash layer was not included in the preliminary quantitative analyses of $\delta^{18} \mathrm{O}$, microparticles by Coulter counter, electrical conductivity, $\mathrm{pH}$ and major ions, of which $50 \mathrm{~cm}$ length samples were taken at $2 \mathrm{~m}$ intervals all through the core (Watanabe and others, 1992). Most of the ash layer has been kept for detailed analyses using more sophisticated techniques in the near future. Preliminary analyses of the ash by SEM and EDS have been made and are presented here.

Several grams of ice were taken from a depth of $500.665-500.700 \mathrm{~m}$, where the concentration of ash was visually thick. The sample was cut and melted in the same way as our other samples. Volcanic ash particles were filtered on to a Nucleo filter and examined by SEM. Two cxamples of ash particles, which look like vesicular 
Higashi and Fujii: Microparticles in ice cores from east Dronning Maud Land, Antarctica

$\mathbf{a}$
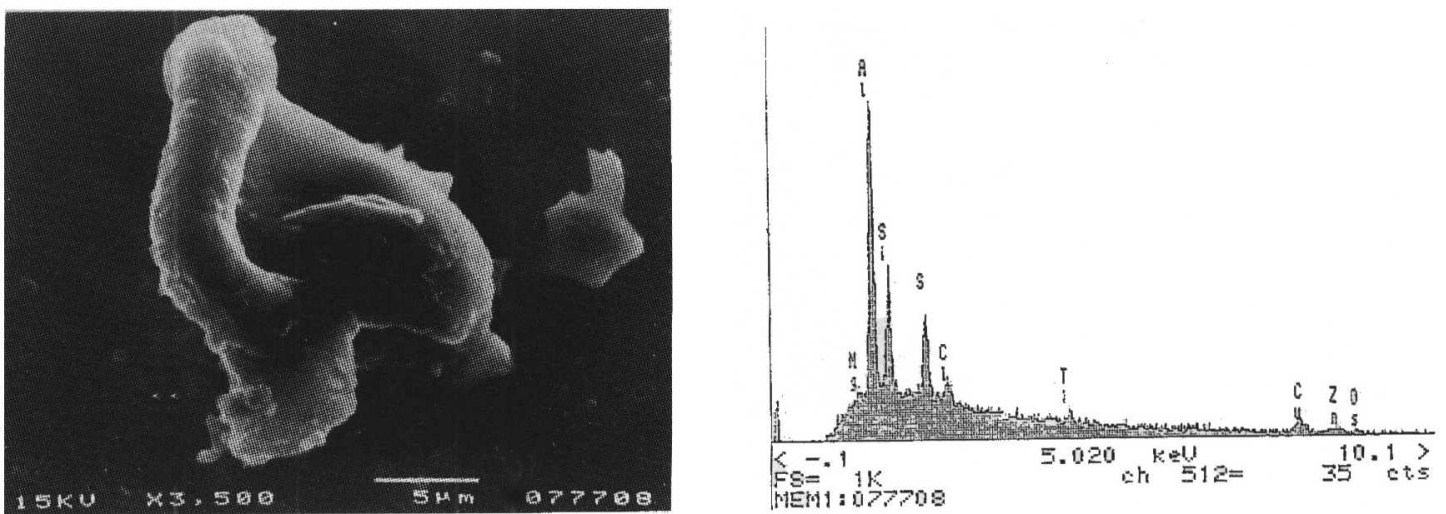

b
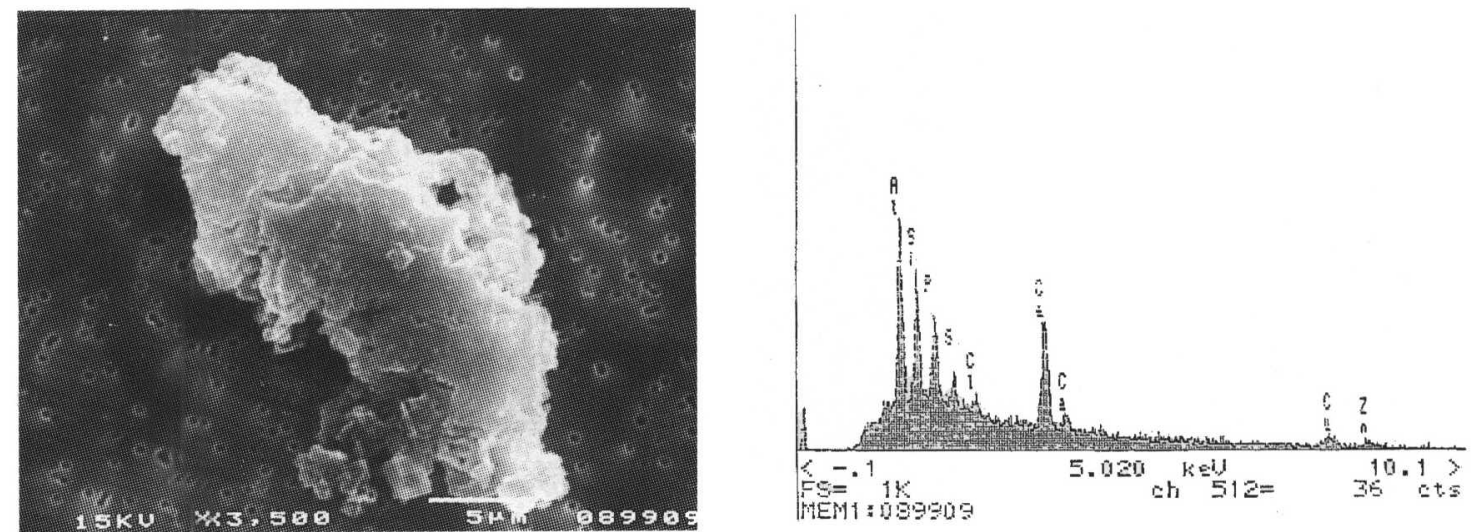

Fig. 3. Varieties of microparticle with EDS charts. a. A particle of convolute shape from $510 \mathrm{~m}$ depth in the Mizuho ice core (approximately 6200 year $B P$ ); b. Ap-lype particle from $570 \mathrm{~m}$ depth in the Mizuho ice core (approximately 7250 year BP).

$\mathbf{a}$
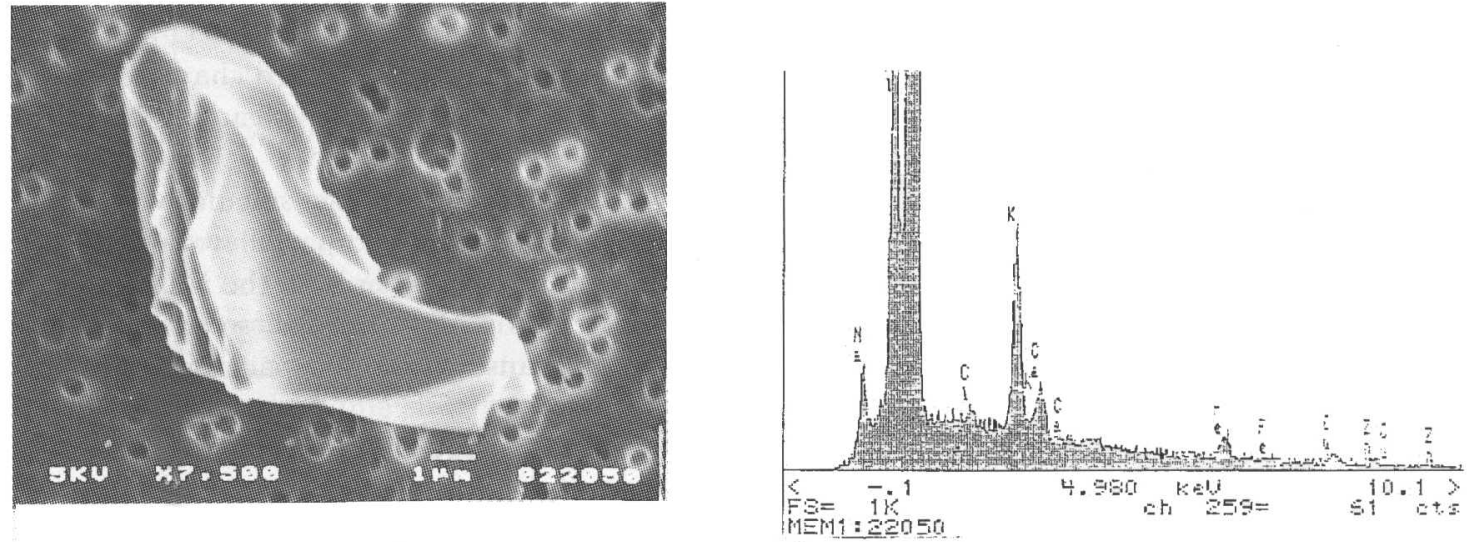

b
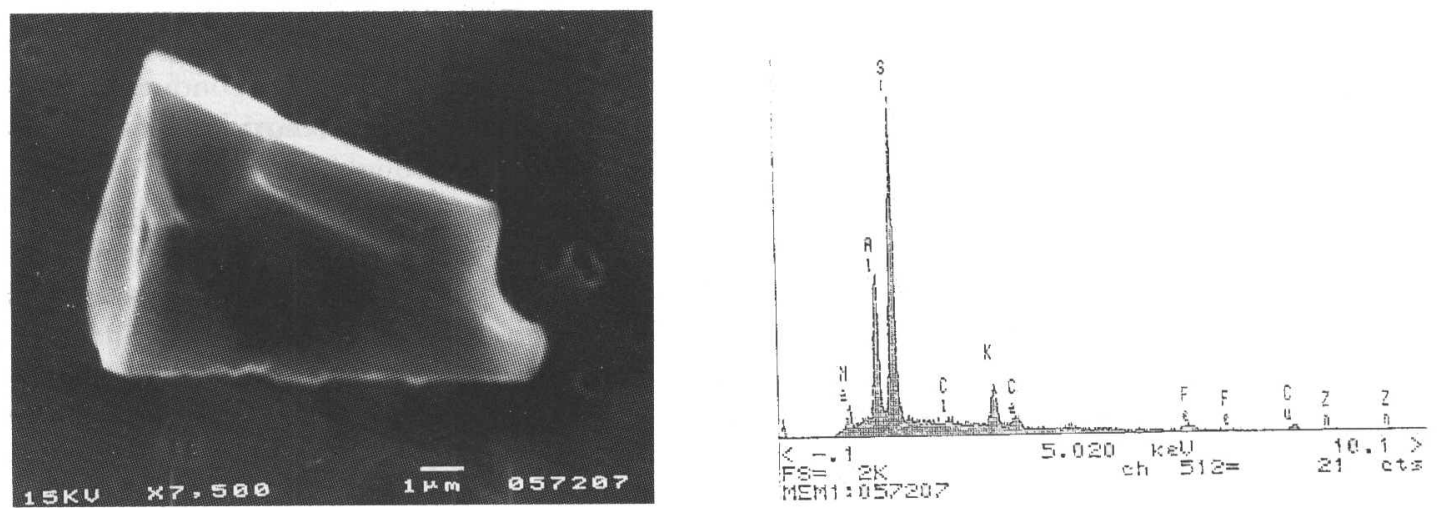

Fig. 4. Particles which look like volcanic ash (glass shards). a. From $220 \mathrm{~m}$ (approximately 2400 year BP); b. From $420 \mathrm{~m}$ depth (approximately 4700 year BP), both from the Mizuho ice core. 
Table 1. Semi-quantitative analyses of oxides contained in individual volcanic ash samples from $500.7 \mathrm{~m}$ depth in the Mizuho ice core (wt \%)

\begin{tabular}{lrrrr}
\hline Particle & & & & \\
Morphology & 505 & 507 & 508 & 509 \\
& $V$ & $V$ & $G$ & $V$ \\
\hline & & & & \\
$\mathrm{SiO}_{2}$ & 56.06 & 51.89 & 50.57 & 48.30 \\
$\mathrm{liO}_{2}$ & 0.52 & 1.47 & 1.43 & 1.46 \\
$\mathrm{Al}_{2} \mathrm{O}_{3}$ & 12.99 & 16.86 & 15.97 & 17.62 \\
$\mathrm{FeO}$ & 16.59 & 13.29 & 16.17 & 15.54 \\
$\mathrm{MgO}$ & 11.47 & 4.86 & 4.22 & 4.64 \\
$\mathrm{CaO}$ & 2.18 & 9.29 & 10.11 & 10.46 \\
$\mathrm{Na}$ & 0.32 & 2.19 & 1.01 & 1.41 \\
$\mathrm{~K}_{2} \mathrm{O}$ & 0.05 & 0.52 & 0.47 & 0.50 \\
& & & & \\
\hline
\end{tabular}

Morphology, G: glass shard; V: vesicular particle.

tephra, are shown in Figure $5 \mathrm{a}$ and $\mathrm{b}$. They correspond to particle No. 507 and No. 509 in Table 1. Among several particles which were analyzed quantitatively by F.DS, two of them exhibited compositions similar to that of feldspars. Results of analyses tabulated in Table I should be considered as semi-quantitative analyses, because of the limited numbers of samples and absence of the reproducibility test.

Computed data for oxides in ash particles from the semi-quantitative analyses tabulated in Table 1 are plotted on a diagram of $\mathrm{Na}_{2} \mathrm{O}+\mathrm{K}_{2} \mathrm{O}$ vs $\mathrm{SiO}_{2}$ (Fig. 6) with other data previously obtained on Antarctic volcanic ash. This figure indicates that this volcanic ash belongs to the non-alkaline area with less $\mathrm{SiO}_{2}$ than any ash in dirt layers found at bare-ice arcas in the Yamato Mountains Katsushima and others, 1984) and near the SorRondane mountains (Naraoka and others, 1991). Results of the oxide concentration in tephra found in South Pole and Vostok ice cores and lava from Candlemas Island (Palais and others, 1987) are also plotted in Figure 6. Ternary plots for $\mathrm{Na}_{2} \mathrm{O}+\mathrm{K}_{2} \mathrm{O}$, FeO and $\mathrm{MgO}$ were made from the data in Table 1 and are

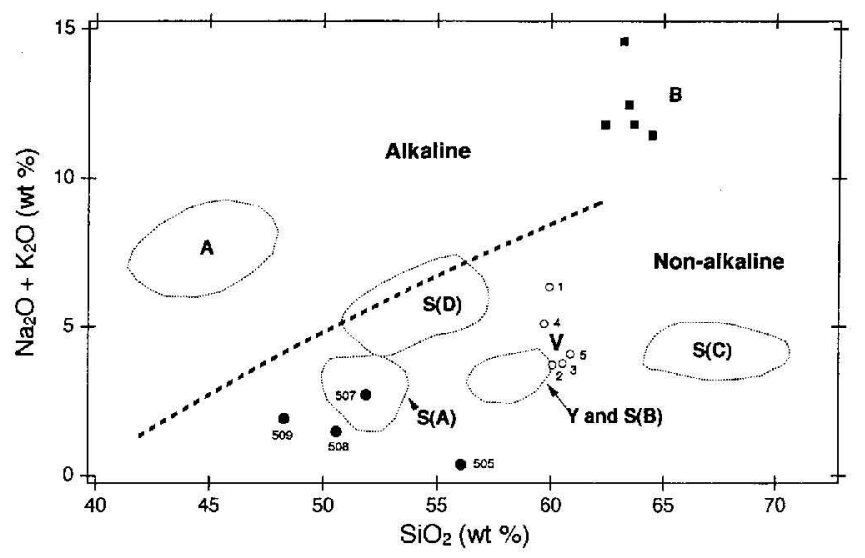

Fig. 6. $\mathrm{Na}_{2} \mathrm{O}+\mathrm{K}_{2} \mathrm{O}$ is $\mathrm{SiO}_{2}$ diagram of analyzed volcanic ash particles sampled from the $500.7 \mathrm{~m}$ depth ash layer (•), with other data of Antarctic volcanic ash: $A$, Allan Hills; $Y$, ramato Mountains (from Katsushima and others, 1984); B, Byrd Station ice core by Palais (1985); V, South Pole tephra (Nos 1 and 2), Vostok tephra (Nos 3 and 4), Candlemas Island lava (No. 5) by Palais and others (1987); and S, Sar-Rondane mountains by Naraoka and others (1991); $A, B, C$ and $D$ in parentheses indicate different locations around the SorRondane mountains.

shown in Figure 7. This also includes other data as mentioned above and it indicates that the ash at $500.7 \mathrm{~m}$ depth is different from any other volcanic ash in Antarcica previously investigated.

\section{DISCUSSION AND CONCLUSIONS}

As has been mentioned in the preceding section, there appear to be increasing fluctuations in the number concentration of microparticles at certain depth ranges shown in Figure 1. Thesc depth ranges are compared with $\delta^{18} \mathrm{O}$ records of the Mizuho ice core (Fujii and Watanabe, $1988,1992) . \Delta \delta^{18} \mathrm{O}$ in Figure 1 is defined as the deviation of $\delta^{18} \mathrm{O}$ values at every $5 \mathrm{~m}$ in the ice core from the smoothed curve of the depth profile as shown in figure 5 of the paper by Higashi and others (1988). This is an index

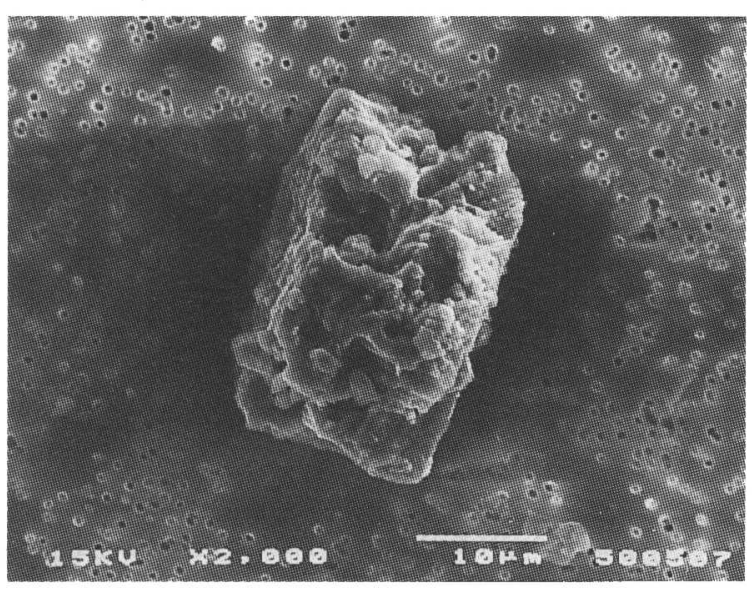

$\mathbf{a}$

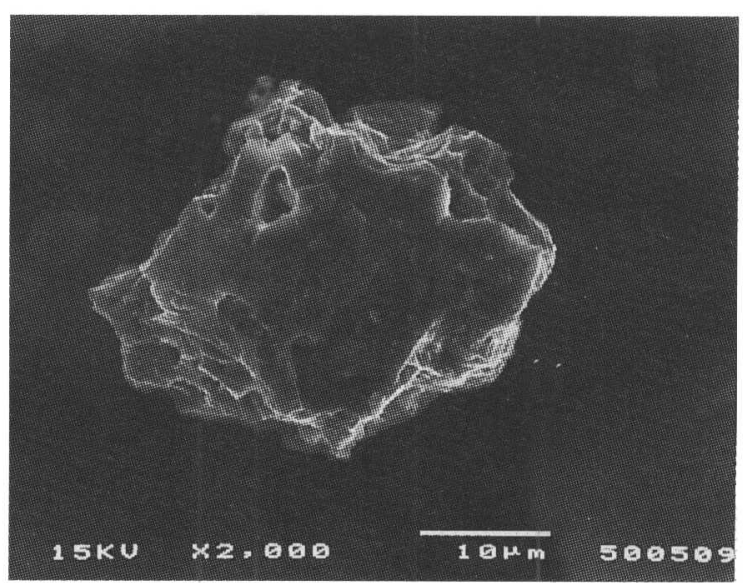

b

Fig. 5. Examples of volcanic ash particles from the $500.7 \mathrm{~m}$ (approximately 6000 year BP) ash layer in the Mizuho ice core; a. Corresponds to particle $\mathrm{No}_{0} .507 ;$ b. Corresponds to particle $\mathrm{No}_{0} .509$, both as analyzed in $\mathrm{T}$ able 1. 


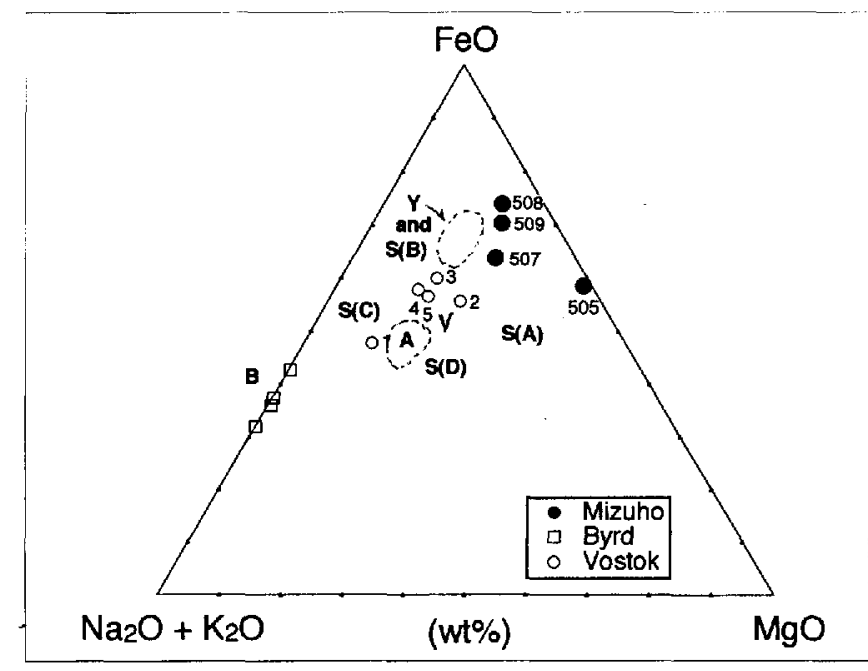

Fig. 7. Ternary diagram of $\mathrm{Na}_{2} \mathrm{O}+\mathrm{K}_{2} \mathrm{O}, \mathrm{FeO}$ and $\mathrm{MgO}$ for the $500.7 \mathrm{~m}$ volcanic ash particles (•) with other data cited in Figure 6.

expressing colder (minus value of $\Delta \delta^{18} \mathrm{O}$ ) or warmer temperatures (plus value of $\Delta \delta^{18} \mathrm{O}$ ) than the average in the Holocene. The curve shown on the righthand side of Figure 1 was obtained by taking the running mean of every five successive values of $\Delta \delta^{18} \mathrm{O}$ for obtaining a longterm trend of climate change. Some cold periods, shown by dark bands at minus deviations, coincide with the depth ranges (e.g. 260-340, 430-450 and 640-670 m) of increased concentration of microparticles shown on the left of the figure. This coincidence may be interpreted in terms of stronger dust inputs appearing to occur in a relatively colder climate even during the Holocene, as occurred more severely in the Last Glacial Maximum (De Angelis and others, 1992).

Although no mineralogical survey was carried out using observed microparticles, clemental compositions shown in EDS charts in the present study indicate that most of the particles belong to minerals such as feldspar, quartz and clay minerals. Since local sources of particles are limited mainly to "dry valleys", arid areas of the Southern Hemisphere located in Australia, South America and southern Africa have been considered as potential long-range continental sources for dust accumulated in the Antarctic ice sheet (Gaudichet and others, 1988). Increase of the dust input in a colder climate, as shown in Figure 1, implies that dust blown from continental sources increased as a result of enhanced aridity and wind activity, both of which are believed to prevail in cold climates.

Volcanic ash found at $500.7 \mathrm{~m}$ depth in the Mizuho ice core was analyzed to identify its origin. As shown in Figure 6, the ash occurs in the lower $\mathrm{SiO}_{2}$ part of the nonalkaline rcgion of the $\mathrm{Na}_{2} \mathrm{O}+\mathrm{K}_{2} \mathrm{O}$ vs $\mathrm{SiO}_{2}$ diagram, where the ash found at $100.8 \mathrm{~m}$ depth in the Vostok core and at $303.44 \mathrm{~m}$ depth in the South Pole core (Palais and others, 1987), and also that found in bare-ice areas in the Yamato and Sor-Rondane mountains occurred (Katsushima and others, 1984; Naraoka and others, 1991). Palais and others (1987) concluded that the volcanic ash both at $100.8 \mathrm{~m}$ depth at Vostok and at $303.44 \mathrm{~m}$ depth in the South Pole ice core originated from Candlemas Island in the South Sandwich Islands, based on a very close similarity of oxide ratios. They estimated the age as 3200 year BP from the accumulation rates and concluded that they can be correlated. Katsushima and others (1984) concluded that the ash found in bare-ice areas near the Yamato Mountains originated from a volcano in the South Sandwich Islands, judging from the $\mathrm{Na}_{2} \mathrm{O}+\mathrm{K}_{2} \mathrm{O}$ vs $\mathrm{SiO}_{2}$ diagram.

Our estimate for the age of the ash is approximately 6000 years, as can be scen from the curve of depth-age relationship shown in Figure 1. The relationship was derived by Nakawo and others (1989) by a new method using a relationship between depth and total strain, which was derived from fabric data of the ice core. This method gave sevcral per cent younger ages than those calculated by a steady-flow model. Judging from Figure 6 and the age estimate, it is concluded that the ash of $500.7 \mathrm{~m}$ depth in the Mizuho ice core originated from the South Sandwich Islands, approximately 6000 years ago. Differences in the composition of the present ash from others that originated from the South Sandwich Islands may be attributed to the different times of eruption.

Extra-terrestrial or cosmic microparticles contained in ice are interesting and useful for the understanding of meteorite fall on the Earth. Although iron micrometeorites have often been found, only one micro-chondrite was found at $110 \mathrm{~m}$ ice depth in the $\mathrm{AC}$ core, as was reported in our previous paper (Higashi and others, 1990). Particles of biological origin will be useful in determining routes of transport of the particles, if the species are identified. This is indecd a subject of future interest.

\section{ACKNOWLEDGEMENTS}

We cordially thank members of ice-core-drilling teams of 23rd, 24th, 26th and 30th JARE parties for their continuing laborious work which made this research possible. We thank Ms Tominaga for her help in sample preparations in NIPR, and Ms Hoshi and Mr Takeya for their hclp in quantitative analyses. We thank Professor $Y$. Katsui, who kindly instructed us about the scries of volcanic eruptions around Antarctica. We are also indebted to anonymous rcviewers, whose critical comments resulted in considerable improvement in this paper. The practice of all SEM observations and EDS analyses was carried out by Mr K. Sasaki, Mr K. Nakamura and $\mathrm{Mr} \mathrm{H}$. Yano as a part of their work for the baccalaureate degree in ICU. Dr S. Fujita's assistance in preparing the manuscript is gratefully acknowledged. This work is a contribution to the Glaciological Research Program in east Dronning Maud Land of the Japanese Antarctic Research Expedition.

\section{REFERENGES}

Briat, M., A. Royer, J. R. Petit and C. Lorius. 1982. Late glacial inpui of eolian continental dust in the Dome $C$ ice core: additional esidence from individual microparticles analysis. Ann. Glaciol., 3, 27-31.

De Angelis, M., N.I. Barkov and V.N. Petrov. 1992. Sources of continental dust over Antarctica during the last glacial cycle. $\mathcal{J}$. Atmos. Chern., 14, 233-244.

Fujii, Y. and O. Watanabe. 1988. Microparticle concentration and electrical conductivity of a $700 \mathrm{~m}$ ice core from Mizuho Station, Antarctica. Ann. Glaciol., 10, 38-42. 
Fujii: $Y$. and O. Watanabe 1992. Paleo-climate and environment rccorded in Antarctic ice cores. In Science in Antarctica. Tokyo, National Institute of Polar Rescarch.

Gaudichet, A., M. De Angelis, R. Leferre, J. R. Petit, Y.S. Korotkevitch and V.N. Petrov, 1988. Mineralogy of insoluble particles in the Vostok Antarctic ice core over the last climatic cycle (150 kyr). (ieophiys. Res. Letl.. 15(13), 1471-1474.

Heiken, G. and K. Wohletz. 1985. Volcanic ash. Berkeley, LA, Lniversity of California Press.

Higashi, A., M. Nakawo, H. Narita, Y. Fujii and O. Watanabc. 1988. Preliminary results of analyses of $700 \mathrm{~m}$ ice cores retrieved at Mizuho Station, Antarctica. Ann. Glaciol.. 10, 52-56.

Higashi, A., Y. Fujii, S. T'akamatsu and R. Watanabe. 1990. SFM observations of microparticles in Antarctic ice cores. Bull. Glac. Res., 8. $31-53$.

Katsushima, T', F. Nishio, H. Ohmae, M. Ishikawa and S. Takahashi. 198.t. Composition of dirt layers in the bare ice areas ncar the Yamato Mountains in Queen Maud Land and the Allan Hills in Victoria Land, Antarctica. Mem. MIPR Spec. Iss., 34, 174-187.

Vakawo, M., H. Ohmae, F. Nishio and \%. Kameda. 1989. Dating the Mizuho $700 \mathrm{~m}$ core from core ice fabric data. Proc. NIPR Symp. Polar Meteorol. Glaciol. 2, 105 110.
Naraoka, H., K. Yanai and S. Fujita. 1991. Dirt bands in the bare ice area around the Sor Rondane Mountains in Queen Maud Land, Antarctica. Antarct. Rec, 35(1), 47-55. [In Japanese.]

NASA. 1992. Cosmic dust calalog. Vol. 13. Houston, TX

Palais, J. M. 1985. Particle morphology, composition and associated ice chemistry of tephra layers in Byrd ice core: evidence for hydrovolcanic cruptions. Ann. Glaciol., 7, 42-48.

Palais, J. M., P. R. Kyle, E. Mosley-Thompson and E. Thomas. 1987. Correlation of a 3,200 year old tephra in ice cores from Vostok and South Polc Stations, Antarctica. Geophys. Res. Lett., 14/8), 804-807.

Palais, J. M., M.S. Germani and G. A. Zielinski. 1992. Inter-hemispheric transport of volcanic ash from a 1259 AD volcanic eruption to the Greenland and Antarctic ice shcets. Geophys. Res. Lett., 1988), 801-804.

Watanabe, O., Y. Fujii and H. Motoyama. 1992. Results of analyses of Mizuho $700 \mathrm{~m}$ ice core, East Antarctica. Part $1.8^{18} \mathrm{O}$, microparticles, ECM (acidity), pH, major ions. JARE Data Reports, 181 (Glaciology 20). Tokyo, National Institute of Polar Research.

The accuracy of references in the text and in this list is the responsibility of the aulhors, to whom queries should be addressed. 